\title{
Maliye Bakanlığı E-Dönüşüm Sürecinin Muhasebe Meslek Mensupları Açısından Değerlendirilmesine İlişkin Bir Alan Araştırması
}

\author{
Seçkin GÖNEN* \\ Bilal SOLAK ${ }^{* *}$
}

ÖZET

Küreselleşme süreci bilgi teknolojilerinde hızl bir ilerlemeyi beraberinde getirmiştir. Bilgi teknolojilerindeki bu değişim; ticari hayatı, mali işlemleri ve sosyal yaşamın tamamında kendini göstermiştir. Ticari ve mali işleyişin önemli aktörlerinden biri Maliye Bakanlığı ve muhasebe meslek mensuplarıdır. Maliye bakanlığl bilgi teknolojilerindeki bu değişime yönelik olarak, vergi gelirlerini artırmak, vergi toplama maliyetini düşürmek ve vergi denetimlerinin etkinliğini artırmak amacı ile e-dönüşümü başlatmıştır. Maliye bakanlığının edönüşüm süreci özellikle muhasebe meslek mensuplarını yakından etkilemiştir. Bu araştırmanın amacı, muhasebe meslek mensuplarının maliye bakanlı̆̆ının e-dönüşümü sürecine ilişkin, iş yükü, hizmet maliyeti vb. konularda bakış açılarını tespit etmektir. Bu amaçla, İzmir 'de faaliyet gösteren ve hali hazırda e-dönüşümü aktif olarak kullanan muhasebe meslek mensuplarına yönelik anket yöntemi uygulanmış ve edinilen bulgular analiz edilmiştir. Yapılan analizler sonucunda e-dönüşümde sistemsel hataların devam ettiği ve meslek mensuplarına ek maliyet getirmesine karşın maliye bakanlığı ile mükellefin işlem maliyetlerini düşürdükleri tespit edilmiştir.

Anahtar Kelimeler: E-dönüşüm, Maliye Bakanlığı, Muhasebe Meslek Mensupları.

JEL Sinıflandırması: M41, M42, M49.

\section{A Field Research Regarding Assessments Of E-Transformation Processes Of Ministry Of} Finance From Accounting Professionals' Viewpoint

\section{ABSTRACT}

A rapid advancement in information technologies is brought by globalization process. This alteration in information technologies manifested itself in commercial life, financial transactions and entire social life. Key actors of financial functioning are ministry of finance and accounting professionals. Important players of financial mechanism are ministry of finance and accounting professionals. E-transformation is commenced in order to increase tax revenues, decrease tax collecting costs and upgrade effectiveness of tax audits by ministry of finance as a respond for altering information technologies. E-transformation process of ministry of finance particularly affected accounting professionals closely.

The aim of this study is to detect viewpoints of accounting professionals about e-transformation process of ministry of finance in specifically issues like workloads and service costs. Serving to this aim, survey method is conducted amongst accounting professionals working in İmir which are active users of e-transformation system. As a result of analysis conducted, it is reached that systematic errors are still being experienced and despite bringing additional costs to accounting professionals, e-transformation has reduced transaction costs of ministry of finance and taxpayers.

Keywords: E-transformation, Ministry of Finance, Accountant Profession

Jel Classification: M41, M42, M49.

\footnotetext{
* Prof. Dr. Seçkin Gönen, Dokuz Eylül Üniversitesi, İktisadi ve İdari Bilimler Fakültesi, seckingonen@hotmail.com

** Yrd. Doç. Dr. Bilal Solak, Dokuz Eylül Üniversitesi, İktisadi ve İdari Bilimler Fakültesi,

bilalsolak23@gmail.com
} 


\section{GíRiş}

Bilgi teknolojilerindeki ilerlemeler sosyo-ekonomik bütün alanları etkisi altına almıştır. Ekonomik yapının önemli bir parçası olan muhasebe uygulamaları da bilgi teknolojilerinde yaşanan değişimden etkilenmiştir.

Muhasebe uygulamalarının önemli bir parçası olan muhasebe meslek mensupları, edönüşüm sürecinde e dönüşüme gönüllü veya zorunlu olarak geçen mükelleflerinden gelen talepler doğrultusunda e-dönüşüme yönelik hizmetler sunmaya başlamışlardır.

E-dönüşüm sürecinin uygulamaya başlanması ile birlikte sistemsel, teknik ve kişilerden kaynaklı çeşitli sorunlar ortaya çıkmıştır. Mevcut sorunlardan etkilenen hiç kuşkusuz muhasebe meslek mensupları olmuştur.

Çalışmada İzmir ilinde faaliyet gösteren ve aktif olarak e-dönüşüm sürecini kullanan muhasebe meslek mensuplarının e-dönüşüm sürecinde yaşadıkları sorunlar tespit edilmeye çalışılmıştır. Çalışmada anket yöntemi kullanılmıştır. Anket katılımcılarına 5 li likert ölçeği kullanılarak hazırlanan sorular ve açık uçlu sorular sorularak mevcut durum tespit edilmeye çalışılmıştır.

Çalışmanın birinci bölümünde, e-dönüşüme ilişkin teorik bilgilere yer verilmiş, ikinci bölümde literatür taramasına yer verilmiştir. Çalışmanın üçüncü bölümünde İzmir ilinde muhasebe meslek mensuplarına uygulanan anket sonuçları değerlendirilmiştir.

Çalışmanın sonucunda, muhasebe meslek mensuplarının hizmet maliyetinde ve iş yüklerinde artış olduğu ayrıca sistemsel sorunların hala devam ettiği tespit edilmiştir. Mükelleflerin işlem ve zaman maliyetlerinin düştüğü tespit edilmiştir.

\section{MALIYYE BAKANLIĞINDA E-DÖNÜŞÜM}

Ülkemizde Elektronik Devlet (e-Devlet) uygulamaları kapsamında elektronik dönüşüm (e-dönüşüm) süreci başlamış ve elektronik ortamda muhasebe uygulamalarına da yansımıştır. Günümüzde işletmelerde bilgi teknolojileri oldukça yoğun bir şekilde kullanılmakta ve bütünleşik bir sisteme dayalı muhasebe sistemleri üretilmektedir. Dolayısıyla söz konusu yazılımlar e-dönüşüm sürecinde önemli katkılar sağlamaktadır (Tektüfekçi, 2016; 22).

E-Dönüşüm ilk olarak 2003-2004 yılı eylem planında 'Vergi beyanı, tahakkuku ve ödemelerinin elektronik ortamda yapılması' şeklinde açıklanmış, 2005 tarihinden itibaren de elektronik beyanname ile uygulanmaya başlamıştır. Daha sonra ise elektronik fatura ve elektronik defter olarak iki önemli hedef belirlenmiştir (Alptürk, 2008; 12).

E-Dönüşüm, işletmelerin muhasebe düzenlerini büyük ölçüde etkilemiş ve değiştirmiştir. $\mathrm{Bu}$ etkiler kayıt, defter, belge ve arşiv gibi alanlarda muhasebe sisteminin 
elektronik ortama aktarılması şeklinde gerçekleşmiştir. Söz konusu etkiler aşağıda özetlenmiştir (Güney ve Özyiğit, 2015; 290)

$\checkmark \quad$ Kayıtlara etkisi: Geleneksel muhasebe sistemlerine göre kayıtlar defter yerine elektronik ortamlara kaydedilmektedir. Günlük işlemler kaydedilirken sınıflandırılarak analize hazır hale gelmektedir. Günlük defterde yapılan herhangi bir kayıt, yeni bir veri girişi yapılmadan defteri kebire aktarılmaktadır. Bununla birlikte kayıt işleminde dijital imza kullanılarak veri girişi yapan kişinin bilgileri kaydedilmektedir.

$\checkmark \quad$ Belgelemeye etkisi: Elektronik muhasebede belgeler, karşılıklı olarak taraflar arasında manyetik ortamda düzenlenmekte ve alıcıya ulaştırılmaktadır. Burada özellikle bilginin güvenilir olması için çalışanın dijital imzanın bulunması oldukça önem arz etmektedir.

Arşive etkisi: Geleneksel muhasebe sisteminden farklı olarak arşiv uygulamaları elektronik muhasebede manyetik ortamda saklanmaktadır. Dolayısıyla fiziki olarak kaydedilmemesi işletme verilerinin korunmasını zorlaştırmakta ve veri depolama alanlarının gerekliliğini gün yüzüne çıkartmaktadır.

$\checkmark \quad$ Raporlamaya etkisi: Finansal tablo kullanıcılarının ve işletme yönetiminin karar alabilmesi açısından gerekli olan finansal ve yönetim raporları çevrimiçi olarak hazırlanabilmekte ve kullanıcılara internet bağlantısı üzerinden hızlı bir şekilde aktarılmaktadır.

Personele etkisi: Elektronik muhasebede, geleneksel muhasebe sistemleri içerisinde görev alan meslek elemanlarından daha farklı özellikler ve yetenekler beklenmektedir. Sistemin elektronik ortamda çalışmasından dolayı, ilgili kişinin muhasebe bilgisinin dışında internet ve bilgi teknolojilerine de hâkim olması beklenmektedir.

Yukarıdaki bilgilerden de görüleceği üzere elektronik muhasebe sistemi, geleneksel muhasebe sistemine göre oldukça farklı uygulamalar içermekte ve farklı gereksinimlere ihtiyaç duymaktadır. Sistemin en önemli unsurlarını ise Elektronik Fatura Kayıt Sistemi (EFKS), e-fatura, e-defter ve e-arşiv oluşturmaktadır.

\subsection{Elektronik Fatura Kayıt Sistemi}

Elektronik Fatura Kayıt Sistemi (EFKS), kurum ve kuruluşların düzenledikleri faturalarda bulunan bazı bilgilerin, belirlenen uygulama ve veri standartları çerçevesinde Gelir İdaresi Başkanlığı sistemine aktarılması şartı ile faturalara ait ikinci nüshaların kağıt olarak saklanması zorunluluğunu ortadan kaldıran; ayrıca alıcılarına verilmek üzere hazırlanan birinci nüsha faturaların da güvenli elektronik imzalı dijital belge şeklinde oluşturulmasına imkan sağlayan pilot bir uygulamadan oluşmuştur (www.efatura.gov.tr).

Türkiye'de 397 sıra no.lu VUK tebliğine ile hayata geçirilen ve 5 Mart 2010 tarihinden itibaren uygulamada olan e-fatura, veri format ve standardı Gelir İdaresi Başkanlığ 
tarafından belirlenen, VUK gereği bir faturada yer alması gereken bilgilerin içerisinde yer aldığgı, satıcı ve alıcı arasındaki iletiminin merkezi bir platform (GİB) üzerinden gerçekleştirildiği elektronik bir belgedir. E-fatura yeni bir belge türü olmayıp, kâğıt fatura ile aynı hukuki niteliklere sahiptir. 397 sıra no.lu VUK ile tüzel kişiler sistemden faydalanabilirken 416 sıra no.lu VUK tebliği ile gerçek kişilere de e-fatura uygulamasına dahil olma hakkı tanınmıştır (www.efatura.gov.tr).

E-fatura uygulama kapsamında V.U.K. mükerrer 242. maddesinin 2 numaralı fıkrasında; "Maliye Bakanlığı, elektronik defter, kayıt ve belgelerin oluşturulması, kaydedilmesi, iletilmesi, muhafazası ve ibrazı ile defter ve belgelerin elektronik ortamda tutulması ve düzenlenmesi uygulamasına ilişkin usul ve esasları belirlemeye, elektronik ortamda tutulmasına ve düzenlenmesine izin verilen defter ve belgelerde yer alması gereken bilgileri internet de dâhil olmak üzere her türlü elektronik bilgi iletişim araç ve ortamında Maliye Bakanlığına veya Maliye Bakanlığının gözetim ve denetimine tâbi olup, kuruluşu, faaliyetleri, çalışma ve denetim esasları Bakanlar Kurulunca çıkarılacak bir yönetmelikle belirlenecek olan özel hukuk tüzel kişiliğini haiz bir şirkete aktarma zorunluluğu getirmeye, bilgi aktarımında uyulacak format ve standartlar ile uygulamaya ilişkin usul ve esasları tespit etmeye, bu kanun kapsamına giren işlemlerde elektronik imza kullanım usul ve esasları düzenlemeye ve denetlemeye yetkili kılınmıştır” ifadesine yer verilmiştir.

421 Sıra Numaralı Vergi Usul Kanunu Genel Tebliği kapsamında;

· 04.12.2003 tarihli ve 5015 sayılı Petrol Piyasası Kanunu kapsamında madeni yă lisansına sahip olanlar ile bunlardan 2011 takvim yılında mal alan mükelleflerden 31.12.2011 tarihi itibariyle asgari 25 Milyon TL brüt satış hasılatına (ciro) sahip olanlar ile,

• 06.06.2002 tarihli ve 4760 sayılı Özel Tüketim Vergisi Kanunu'na ekli (III) sayılı listedeki malları imal, inşa veya ithal edenler ile bunlardan 2011 takvim yılında mal alan mükelleflerden 31.12.2011 tarihi itibariyle asgari 10 Milyon TL brüt satış hasılatına (ciro) sahip olanlar,

“01.09.2013 tarihine kadar Gelir İdaresi Başkanlı̆̆ı'na başvurmak ve 31.12.2013 tarihine kadar e-fatura uygulamasına geçme" zorunluluğu getirilmiştir.

E-belge, e-fatura, e-imza, e-bildirge gibi uygulamalar e-dönüşümü oluşturmakta, internetin gücünden faydalanarak tüm operasyonların eskisinden çok daha verimli, çok daha düşük maliyetli ve çok daha esnek yönetilmesini sağlamaktadır (Hacırüstemoğlu, 2008:3).

\subsection{E-Faturanın Faydaları}

Kâğıt tabanlı faturalamanın aksine e-faturada tüm verilerin dijital ortamda oluşturulması önemli yararlar sağlamaktadır. Öncelikli olarak faturaların daha kısa sürede ilgililere ulaşması ödeme gecikmelerini azaltmaktadır. Bununla birlikte fatura üretirken daha az hata, daha az baskı ve posta maliyeti oluşmakta ve sistemin tüm birimlerle entegre olarak 
çalışması bilgi akışını hızlandırmaktadır. Dolayısıyla e-faturanın ayırt edici bir özelliği, faturanın yapılandırılmış bir sistem içerisinde gönderilmesi durumunda otomasyona olan potansiyelidir. E-Fatura; ihraççı ya da hizmet sağlayıcının finansal tedarik zinciri sistemlerinde otomatik olarak ve doğrudan alıcıya aktarılması ile sadece baskı ve posta masraflarından elde edilen tasarruf ile ekonomik fayda sağlamamakta, aynı zamanda siparişin hızlı tamamlanması ile taraflar arasındaki ödeme süresini kısaltmaktadır. Son olarak kağıt tüketiminin azalması ve ulaşım için harcanan enerji maliyetlerinin düşürülmesi açısından efaturalamanın çevresel faydaları da önem arz etmektedir (European Commission, 2010:3).

\subsection{E-Defter}

E-defter, Vergi Usul Kanunu ve Türk Ticaret Kanunu hükümleri gereğince tutulması zorunlu olan defterlerin bu sitede duyurulan format ve standartlara uygun biçimde elektronik dosya biçiminde hazırlanması, bastırılmaksızın kaydedilmesi, değişmezliğinin, bütünlügünün ve kaynağının doğruluğunun garanti altına alınması ve ilgililer nezdinde ispat aracı olarak kullanılabilmesine imkan tanımayı hedefleyen hukuki ve teknik düzenlemeler bütünüdür (www.edefter.gov.tr).

E-defter, hem mükelleflerin hem de birçok kamu ve özel sektör kurumunun vergisel ve vergisel olmayan birçok amacına katkıda bulunacak olan bir uygulamadır. Elbette bilgi teknolojilerinin bu kadar yoğun olarak kullanıldığı günümüzde diğer ülkelerdeki benzer uygulamalara paralel olarak e-defter uygulamasının ülkemizde de hayata geçirilmesi bir gerekliliğin ötesinde artık bir zorunluluk halini almıştır. Ayrıca e-defter, mükelleflerin uyum maliyetlerine ciddi katkı sağlayacaktır. Bu kapsamda e-deftere geçilmesinin amaçlarını aşağıdaki gibi sıralamak mümkündür (Doğan, 2012; 17):

$\checkmark \quad$ Defter kayıtlarının oluşturulması ile ilgili yükümlülükleri değișen teknolojik ve idari ihtiyaçlara uygun biçimde revize etmek,

$\checkmark \quad$ Kâğıt ortamında basım, tasdik ve saklama yükümlülüklerini ortadan kaldırmak suretiyle bu yükümlülüklerin elektronik ortam ve araçlarla yerine getirilebilmesine imkân sağlamak,

$\checkmark \quad$ Mükellef hizmetlerinde ve idari işlemlerde yeni açılımlar sağlamak,

$\checkmark \quad$ Vergiye gönüllü uyumu artırmak,

$\checkmark \quad$ Elektronik denetim için uygun altyapıyı oluşturmak ve yerleştirmek,

$\checkmark \quad$ Uzaktan denetim yapabilmenin kapısını aralamak,

$\checkmark \quad$ Uluslararası ortak denetime imkan sağlamak,

$\checkmark \quad$ Farklı yasal ortamlarda faaliyet gösteren uluslararası firmaların hem yönetsel hem de iç ve dış denetimleri ihtiyaçları için ortak bir format ve standart sağlamak, 
E-defter uygulaması şüphesiz sadece Maliye Bakanlığı uygulamaları için değil, firmalardan çeşitli sebeplerle (örneğin bankalarca kredi taleplerinin değerlendirilmesi) bilgi ve raporlamalar isteyen diğer kamu ve özel sektör kurumları için de standart bir veri formatında bilgiler sunacağı için hayati öneme sahiptir.

\subsection{Arşiv}

433 Seri No’lu Vergi Usul Kanunu Genel Tebliği ile yürürlüğe giren e-arşiv uygulaması, Gelir İdaresi Başkanlığı tarafından belirlenen standartlara uygun olarak faturanın elektronik ortamda oluşturulması, elektronik ortamda muhafazası, ibrazı ve raporlamasını kapsayan bir uygulamadır. E-arşiv uygulamasından yararlanmak isteyen mükelleflerin, öncelikle e-fatura uygulamasına kayıtlı olmaları gerekmektedir. Elektronik Fatura Kayıt Sistemi (EFKS) kapsamında faturalarını elektronik ortamda oluşturma ve muhafaza izni almış olan mükellefler, 1/4/2015 tarihinden geç olmamak üzere Başkanlığın kendilerine yazıyla bildireceği bir tarihte e-arşiv uygulamasına geçmek zorundadırlar. İnternet üzerinden mal ve hizmet satışı yapan ve 2014 yılı gelir tablosu brüt satış hasılatı tutarı 5 milyon lira ve üzerinde olan mükelleflerin, en geç 1/1/2016 tarihine kadar e-arşiv uygulamasına geçme zorunluluğu getirilmiştir. 2017 yılı için bu rakamlar güncelliğini korumaktadır (www.efatura.gov.tr).

\section{DÖNÜŞÜMÜN MUHASEBE MESLEK MENSUBUNA ETKİSi}

Bilgi teknolojilerinin muhasebe uygulamaları içine entegre edilmesi e-dönüşüm sürecini başlatmış, yaşanan ekonomik ve teknolojik gelişmeler ise muhasebe meslek mensuplarının çalışma şekillerini önemli ölçüde değiştirmiştir. E-fatura ve e-defter uygulamaları, hali hazırda muhasebe uygulamalarında var olan bilgisayar kullanımını daha da önemli hale getirmiş ve gerçekleştirilen hizmetin büyük bir bölümünü bilgisayar ortamına taşımıştır. Muhasebe çalışanları; sürekli geliştirilen yeni uygulamalar nedeniyle iyi bir muhasebe sisteminin kullanılabilmesi için gerekli olan muhasebe eğitiminin yanında artık iyi birer bilgisayar kullanıcısı da olmak zorundadırlar.

E-dönüşümün muhasebe meslek mensupları üzerindeki etkileri aşağıda özetlenmiştir (Hatunoğlu ve Bakan, 2010; 124 ve Çetin ve Eren, 2015; 99); arttırmasidir.

E-dönüşümün en önemli etkisi zaman tasarrufu sağlayarak verimliliği Defter tutma işlemi daha da kolaylaşmıştır.

Yapılan işlemler hızlanmış ve daha açık, anlaşılır bir hal almıştır.

Oto kontrolü sağladığı için hata yapma olasılığı azalmıştır.

Daha az iş gücüne ihtiyaç duyulması sebebiyle maliyetler azalmıştır.

İş performansını arttırıcı özellikler ortaya çıkmıştır. 
$>\quad$ Mesleki gelişmelerin takibi kolaylaşmıştır.

> Yapılan işin kalitesine olumlu etki ederek müşteri memnuniyetini arttırmaktadir.

$>$ Bilginin aktarılması hız kazanmış, zamandan sıkıntısından dolayı yaşanan gelişmeler ortadan kalkmıştır.

$>\quad$ Çalışma ortamında iş yapma isteğini olumlu yönde değiştirmiştir.

$>\quad$ İletişim maliyetlerini azaltmıştır.

E-dönüşüm sayesinde kayıt altına alınan belgelerin ve defterlerin elektronik ortamda kaydedilmesi, aktarılması ve depolanması ile oluşturulan sistem, yalnızca işletme maliyetlerini düşürmeye yardımcı olmamakta, aynı zamanda finans ve diğer yargı konularında daha kolay ve daha etkin bir denetimi mümkün kılmaktadır (Güney, 2014; 855).

\section{LITERATÜR TARAMASI}

Aşağıda e- dönüşüm ve elektronik muhasebe sürecine ilişkin farklı açılardan ele alınan ulusal ve uluslararası belli başlı çalışma bulgularına yer verilmiştir.

Hatunoğlu ve Bakan (2010) muhasebe bürolarında bilgisayar ve internet kullanımının faydaları ile işyeri özellikleri arasındaki ilişkileri incelemek adına bir alan araştırması yapmıştır. Dönem itibari ile elde edilen bulgularda muhasebe meslek mensuplarının bilgisayar ve internet kullanımlarının beklenen düzeye henüz ulaşmadığını ancak belirli alanlarda kullanıldığını belirlemişlerdir. Dolayısıyla beklenen faydanın önemli bir kısmı elde edilememektedir. Bilgi teknolojilerinden yararlanma düzeyi arttıkça elde edilen faydalarda da artış sağlanacağı ise yapılan çalışma sonucunda tespit edilmiştir.

Amidu vd. (2012) Gana'da bulunan KOBİ'lerin e-muhasebe uygulamalarını analiz etmiş ve söz konusu işletmelerin neredeyse tamamının bünyesinde muhasebe meslek mensubu çalıştırdığ 1 tespit edilmiştir. Çalışmada elde edilen bulgularda işletmeler çoğunlukla mali bilgileri üretmek amacıyla e-muhasebe yazılımları kullanmakta, maliyetleri düşürme, büro çalışmalarını geliştirme, veri saklamak için yeterli alan ve yönetim kararlarına ilişkin bilgilerin hızlı bir şekilde kaydedilmesi açısından da önemli bir avantaj elde etmektedirler.

Çınar ve Güney (2012) yaptıkları çalışmada muhasebe meslek mensuplarının elektronik uygulamalardan oldukça yüksek düzeyde etkilendiğini belirlemiş ve bu sorunlar üzerine Erzurum ilinde bulunan ve anket formunu eksiksiz olarak dolduran 105 kişi ile bir araştırma gerçekleştirmiştir. Elde edilen bulgulardaki en önemli sorun Gelir İdaresi sistemlerinde ortaya çıkan aksaklıklar ve bilişim altyapısının yetersizliğinden kaynaklanan erişim zorluğudur. Ayrıca mevzuat değişikliklerinin zamanında sisteme uyarlanmaması bir değer sorunu ortaya çıkarmıştır. Çalışmada son olarak meslek mensuplarının muhasebe 
yazılımları ve internet bilgileri üzerindeki yetersizlikleri ortaya konmuş ve meslek adaylarına yeterli düzeyde eğitimlerin verilmesi gerektiği belirtilmiştir.

Tektüfekçi (2013) bilişim uygulamalarındaki gelişmelerin muhasebe üzerindeki etkilerini incelemiş, elektronik ortamda düzenlenen e-Fatura, e-Defter ve diğer muhasebe uygulamaların gerçekleştirilmesi ile birlikte matbaa basım ve ciltleme, noter tasdik, arşivleme-depo, işgücü, zaman, yazıcı toner/kartuş maliyetlerinde önemli ölçüde tasarruf sağlanacağını tespit etmiştir.

Güney (2014), teknolojik gelişmelerin muhasebe faaliyetleri kapsamında görevleri yerine getirme yöntemlerini değiştirdiğini belirtmiş, elektronik ortamda yapılan muhasebe kayıtlarının işleme sürecinde bilgi teknolojilerinin önemini vurgulamıştır. Dolayısıyla değişen muhasebe uygulamalarına uyum sağlamak için eğitimcilere ve uygulamacılara yeni görevler yüklendiğini ve teorik bilgilere teknolojik faktörlerin dahil edilerek ders anlatılması gerektiğini açıklayarak muhasebe eğitiminin kalitesinin işletme ve dolayısıyla muhasebe meslek mensuplarının başarısına doğrudan etki eden bir faktör olduğunu ortaya koymuştur.

Spoz (2014) elektronik faturanın kağıt faturaya oranla çok iyi bir alternatif olduğunu belirtmiş ve e-faturaların girişi sırasında elde edilen zaman ve para tasarrufunun dışında faturalama sürecini kolaylaştırdığı için muhasebe elemanlarına kolaylık sağladığını tespit etmiştir. Çalışmada Avrupa Birliği ülkelerinden gelen veriler incelenerek bir yıl içerisinde faturalama maliyetlerinde toplamda 240 milyon Euro'luk bir tasarrufun sağlandığ görülmüştür.

Lian (2015), Tayvan’da e-faturanın benimsenmesi için kritik faktörleri anlamak adına bir ampirik çalışma gerçekleştirmiştir. Anket yoluyla gerçekleştirilen çalışmada toplamda 251 katılımcı bulunmakta ve elde edilen bulgularda e-fatura uygulamasının mevcut şartlar göz önünde bulundurulduğunda e-devlete olan güven ve algılanan risk düzeyi arasında toplumsal cinsiyet farklılıklarının, sosyal etkinin ve davranışsal niyetin karar vermede aşamasında belirleyici rol oynadığını tespit etmiştir.

Marinagi vd. (2015) Yunanistan'da e-faturanın benimsenmesini ve kullanılmasını belirlemek için bir saha araştırması gerçekleştirmişlerdir. 42 adet Yunan işletmesinden oluşan çalışma, özellikle e-faturanın kullanımını engelleyen konular üzerinde soruşturma gerçekleştirmiş ve e-faturalandırmayı uygulamak için gerekli bilgi birikiminin yeterli olmaması ve yönetim desteğinin bulunmaması olmak üzere iki ana sorun üzerinde yoğunlaşmıştır.

Gökçen ve Özdemir (2016) e-fatura ve e-defter uygulamalarının muhasebe meslek mensuplarına sağladığı avantajları ve dezavantajları incelemiştir. Çalışmada elde edilen bulgulara göre söz konusu uygulamalar kolay erişim, arşivleme, maliyet tasarrufu açısından avantaj sağlarken, altyapı yetersizliği, güvenlik, yasal zorunluluk gibi sebeplerden ötürü de bazı zorluklara neden olmaktadır. 


\section{ARAŞTIRMANIN METODOLOJISI}

Bu bölümde çalışmanın amacı kapsamı ve analiz sonuçlarına yer verilmiş ve sonuçlar yorumlanmiştır.

\subsection{Araştırmanın Amacı}

$\mathrm{Bu}$ araştırmanın temel amacı, muhasebe meslek mensuplarının Maliye Bakanlı̆̆g'nın e-dönüşümü sürecine ilişkin, yaşadıkları sorunlar, çözüm önerileri, iş yüklerine etkisi ve hizmet maliyetlerine etkisini tespit etmektir. Bu amaçla, İzmir ili merkez ilçelerde faaliyet gösteren ve hali hazırda e-dönüşümü aktif olarak kullanan muhasebe meslek mensuplarına yönelik anket yöntemi kullanılmış ve bulgular analiz edilmiştir.

\subsection{Araştırmanın Kısıtları}

Çalışmamızın verileri, İzmir ili merkez ilçelerinde bağımsız olarak faaliyet gösteren muhasebe meslek mensuplarına uygulanmıştır. Bu durum aynı zamanda çalışmamızın kısıtını oluşturmaktadır. İzmir ilinin tercih edilmesinin nedeni, gelişmiş bir ekonomisinin olması ve Maliye Bakanlığı'nın e-dönüşüm sürecinde e-dönüşümü kullanan mükellef sayısının fazla olmasidir.

\subsection{Araştırmanın Yöntemi}

Çalışmanın veri kaynağı olarak, araştırmada kullanılan temel araştırma metodolojisi ankettir. Yöntem, göz atım araştırmalarında en önemli bilgi toplama aracı olup, cevaplayıcılardan istenen bilgileri elde etmek için biçimlendirilmiş bilgi formlarıdır (Nakip, 2006:119). Anket uygulaması İzmir ili merkez ilçelerinde bağımsız olarak faaliyet gösteren muhasebe meslek mensuplarına uygulanmıştır. Çalışmada 5'li likert ölçeği kullanılmıştır. Ölçekte sayısal değerler şu şekilde belirlenmiştir: 1= Kesinlikle Katılmıyorum, 2= Kat1lmiyorum, 3= Fikrim Yok, 4= Katıliyorum ve 5= Kesinlikle Katıliyorum. Ayrıca anketimizde açık uçlu sorulara da yer verilerek muhasebe meslek mensuplarının ankete bağlı kalmaksızın görüşlerini belirtmeleri hedeflenmiştir.

Anket 27 sorudan oluşmaktadır. 27 sorunun 6 tanesi demografik özelliklerine yönelik olarak sorulmuştur. Anket formunda ayrıca 2 tane açık uçlu soru sorularak cevaplayıcıların anket dışında belirtmesi gereken durumların tespitinin sağlanmasına çalışılmıştır. Çalışmanın anketin giriş kısmında sadece e-dönüşümü kullanan muhasebe meslek mensuplarının anketi cevaplaması istenmiştir. Bu şekilde cevaplayıcıların verecekleri yanıtların daha objektif olması hedeflenmiştir.

\subsection{Araştırmanın Kapsamı}

Çalışmamızın kapsamını İzmir ili merkez ilçelerinde faaliyet gösteren bağımsız muhasebe meslek mensupları oluşturmaktadır. İzmir ili merkez ilçelerinde 878 muhasebe 
meslek mensubu faaliyet göstermektedir ve bu sayı aynı zamanda çalışmamızın evrenini oluşturmaktadır. Çevrimiçi olarak oluşturulan anket formları İzmir SMMM odasının izni ve desteği ile merkez ilçelerinde bağımsız faaliyet gösteren bütün muhasebe meslek mensuplarına gönderilmiştir. Çevrimiçi anket formunu sadece aktif olarak e-dönüşümü kullanan muhasebe meslek mensuplarının yanıtlaması istenmiştir. Çalışma kapsamında, İzmir ili merkez ilçelerinde faaliyet gösteren 174 muhasebe meslek mensubu çalışmamıza katılmayı kabul etmiştir. Ancak 12 anket eksik doldurulmuş olup çalışmanın güvenirliğini etkileyeceği için analiz dışı bırakılmıştır. Toplamda 162 anket analize tabi tutulmuş ve sonuçlar yorumlanmıştır.

Tablo 1. Çalışmanın Ana kütlesi ve Ankete Katılan Meslek Mensuplarının Sayısı

\begin{tabular}{lll}
\hline İzmir & 878 & 162 \\
\hline Toplam & 878 & 162 \\
\hline
\end{tabular}

Çalışma kapsamında elde edilen örneklem sayısı olan 162 Yazıcığlu ve Erdoğan (2004) tarafından belirtilen 500-1000 arasındaki evrenler için yüzde 5 hata payı ile kabul edilebilir nitelikte bir örneklem olduğu görülmektedir.

\subsection{Araştırmanın Bulguları}

$\mathrm{Bu}$ bölümünde çalışmamızın bulguları verilerek literatüre dayalı tartışılmıştır.

Tablo 2. Ankete Katılan Meslek Mensuplarına Ait Demografik Özellikler

\begin{tabular}{|l|l|l|}
\hline Cinsiyet & Gözlem Sayıs1 & Yüzde \\
\hline Kadın & 37 & $\% 22.8$ \\
\hline Erkek & 125 & $\% 77.2$ \\
\hline Yaş & Gözlem Sayıs1 & \\
\hline $23-30$ & 10 & $\%$ 6,2 \\
\hline $31-37$ & 50 & $\% 30,9$ \\
\hline $38-45$ & 43 & $\% 26,5$ \\
\hline $46-53$ & 29 & $\% 17,9$ \\
\hline 53 ve üstü & 30 & $\% 18,5$ \\
\hline Tecrübe & & Yüzde \\
\hline $0-5$ & Gözlem Sayıs1 & $\% 4,3$ \\
\hline $6-11$ & 7 & $\% 13,0$ \\
\hline $12-17$ & 21 & $\% 26,5$ \\
\hline $18-23$ & 43 & $\% 22,2$ \\
\hline 23 ve üstü & 36 & $\% 34,0$ \\
\hline İşletme Türü & 55 & Yüzde \\
\hline Ulusal & Gözlem Sayı1s1 & $\% 93.2$ \\
\hline Uluslararas1 & 151 & $\% 6.8$ \\
\hline
\end{tabular}




\begin{tabular}{|l|l|l|}
\hline Mezuniyet & Gözlem Sayıs1 & \\
\hline SMMM & 162 & $\% 100$ \\
\hline SMMM+Bağımsız Denetçi & 27 & $\% 15.9$ \\
\hline Eğitim & Gözlem Sayısı & Yüzde \\
\hline Lisans & 133 & $\% 82.1$ \\
\hline Yüksek Lisans & 29 & $\% 17.9$ \\
\hline Doktora & 0 & $\% 0$ \\
\hline
\end{tabular}

Tablo 2 incelendiğinde araştırmamıza katılan meslek mensuplarından yüzde 77,2'sinin erkek iken yüzde 22,8'sinin kadın olduğu görülmüştür. Ayrıca mesleki deneyimleri incelendiğinde meslek mensuplarının 1-11 yıl arasında yüzde 17,3’lük bir paya, 10 yıl üstü ise yüzde 82,7’lik paya sahip olduğu görülmektedir. Mesleki deneyim ile e-dönüşüme ilişkin sorun yaşama arasında ve cinsiyet ile e-dönüşüme ilişkin sorun yaşama arasında istatistiki olarak anlamlı bir ilişski tespit edilememiştir. Tablo 2'ye göre, meslek mensuplarının yüzde 82,1'inin lisans mezunu olduğu buna karşın yüksek lisans derecesine sahip olan muhasebe meslek mensubunun sadece yüzde 17,9 olduğu görülmektedir. Doktora mezunu meslek mensubu ise bulunmamaktadır. Genç meslek mensuplarının güncel gelişmeleri takip edebilmeleri ve teorinin uygulamaya dönüşümünün hızlandırılması için, lisansüstü eğitime teşvik edilmesi gerektiği düşünülmektedir. Çalışma kapsamında yüksek lisans eğitimi ile edönüşüme ilişkin sorun yaşama arasında istatistiki olarak anlamlı bir ilişki tespit edilememiştir. E-dönüşümde sistemsel ve yazılım programlarından kaynaklı olmasının bu durumun temel nedeni olduğu düşünülmektedir.

Tablo 3. Mükellefin E-dönüşüme Dahil Olma Süreci

\begin{tabular}{|l|c|c|}
\hline Cevap & Gözlem Sayısı & Yüzde \\
\hline Zorunlu olarak katılım & 154 & 95,1 \\
\hline Gönüllü olarak katılım & 8 & 4,9 \\
\hline
\end{tabular}

Tablo 3’de mükelleflerin e-dönüşüm sürecine gönüllü mü, yoksa zorunlu olarak m1 katıldığ 1 tespit edilmeye çalışılmıştır. Tablo 3 incelendiğinde mükelleflerin yüzde 95,1'nin edönüşüm sürecine zorunlu olarak geçtiği görülmüştür. Alınan yanıtlardan mükelleflerin edönüşüm sürecine katılımı istemedikleri düşünülmektedir. Bu durumun temel nedeni olarak muhasebe meslek mensuplarının hizmet maliyetlerini artırması ve ayrıca sistem entegrasyonunun getirmiş olduğu ek maliyetlerin olduğu düşünülmektedir. 
Tablo 4. E-dönüşüm Süreci ve İşlemlerine Yönelik Seminer/Eğitim Katılım Durumu

\begin{tabular}{|l|c|c|}
\hline Katılım Sayıs1 & Gözlem Sayıs1 & Yüzde \\
\hline $1-3$ & 78 & 48,1 \\
\hline $4-7$ & 34 & 21,0 \\
\hline $8-11$ & 10 & 6,2 \\
\hline Hiç Katılmadım & 40 & 24,7 \\
\hline
\end{tabular}

Tablo 4'de muhasebe meslek mensuplarının e-dönüşüme yönelik eğitim seminerine katılımlarını ölçmeye yönelik soru sorularak cevap aranmıştır. Alınan yanıtlardan yüzde 75,3'ünün en az bir eğitime katıldıkları, buna karşın yüzde 24.7'sinin ise eğitime hiç katılmadıkları tespit edilmiştir. Çalışma kapsamında şirketlerin türü ile eğitim seminere katılım arasında bir ilişki olup olmadığı araştırılmıştır. Analiz sonucunda, uluslararası şirketlere hizmet veren muhasebe meslek mensuplarının 1-3 eğitime katılanlar içerisinde yüzde 100 oluşturduğu tespit edilmiştir. Bu durum uluslararası şirketlere hizmet sunan muhasebe meslek mensuplarının hizmet kalitelerini artırmada daha duyarlı davrandıkları düşünülmektedir.

Tablo 5. E-dönüşüm Süreci ve İşlemlerine Yönelik Seminerin/Eğitimin Nereden Alındığ 1

\begin{tabular}{|l|c|c|}
\hline Cevap & Gözlem Sayısı & Yüzde \\
\hline SMMM Odasından & 106 & 65,4 \\
\hline Maliye Bakanlığından & 16 & 9,9 \\
\hline Herhangi Bir Yerden Almadım & 40 & 24,7 \\
\hline
\end{tabular}

Tablo 5 incelendiğinde yüzde 65,4'nün meslek odalarından eğitim aldıkları tespit edilmiştir.

Tablo 6. E-dönüşüm Süreci ve İşlemlerinde Sorun Yaşama Sıklığ1

\begin{tabular}{|l|l|l|}
\hline Cevap & Gözlem Sayısı & Yüzde \\
\hline 1-5 Arası sorun yaşadım & 63 & 38,9 \\
\hline 6-11 Arası sorun yaşadım & 27 & 16,7 \\
\hline 12-17 Arası sorun yaşadım & 18 & 11,1 \\
\hline 18-23 Arası sorun yaşadım & 5 & 3,1 \\
\hline 23 ve Üstü sorun yaşadım & 32 & 19,8 \\
\hline Hiç Sorun yaşamadım & 17 & 10,5 \\
\hline
\end{tabular}

Muhasebe meslek mensuplarının e-dönüşüm sürecinde kaç kez sorun yaşadıklarına yönelik yanıtları Tablo 6 verilmiştir. Muhasebe meslek mensuplarının yüzde 89,5 nin en az 
bir kez sorun yaşadıkları tespit edilmiştir. Ayrıca uluslararası şirketlere hizmet veren muhasebe meslek mensuplarının ulusla şirketlere hizmet verenlere göre sorun yaşamama oranını belirlemeye yönelik yapılan analizde pozitif yönlü anlamlı bir sonuç tespit edilmiştir.

Tablo 7. E-dönüşüm Süreci ve İşlemlerinde Hata yapma Sıklığı

\begin{tabular}{|l|l|l|}
\hline Cevap & Gözlem Sayıs1 & Yüzde \\
\hline 1-5 Arası hata yaptım & 75 & 46,3 \\
\hline 6-11 Arası hata yaptım & 28 & 17,3 \\
\hline 12-17 Arası hata yaptım & 10 & 6,2 \\
\hline 18-23 Arası hata yaptım & 6 & 3,7 \\
\hline 23 ve Üstü hata yaptım & 16 & 9,9 \\
\hline Hiç hata yapmadım & 27 & 16,7 \\
\hline
\end{tabular}

Muhasebe meslek mensuplarının e-dönüşüm sürecinde kaç kez hata yaptıklarına yönelik yanıtları Tablo 7'de verilmiştir. Muhasebe meslek mensuplarının yüzde 83,3 ünün en az bir kez hata yaptıkları tespit edilmiştir. Muhasebe meslek mensuplarının eğitim yetersizlikleri, sistemsel hatalar ve kullandıkları programdan kaynaklı sorunların, bu yüksek oranda hata yapılmasının nedeni olabileceği düşünülmektedir.

Tablo 8. Kullanmakta olduğum muhasebe programı e-dönüşüm için yeterli alt yapıya yönelik yanıtları

\begin{tabular}{|l|l|l|}
\hline Cevap & Gözlem Sayısı & Yüzde \\
\hline Kesinlikle Katılmıorum & 9 & 5,6 \\
\hline Katılmiyorum & 9 & 5,6 \\
\hline Fikrim Yok & 46 & 28,4 \\
\hline Katıliyorum & 46 & 28,4 \\
\hline Kesinlikle Katıliyorum & 52 & 32,1 \\
\hline
\end{tabular}

Muhasebe meslek mensuplarının kullanmakta oldukları muhasebe programlarının edönüşüm için yeterli alt yapısına yönelik yanıtları tablo 8'de verilmiştir. Çalışmaya katılan katılımcıların sadece yüzde 11'2'si programlarının yetersiz olduklarını beyan etmişlerdir. Muhasebe paket programları sunan şirketlerin e-dönüşüm için yeterli teknik alt yapıyı kullanıcılarına sundukları bu durumun nedeni olabileceği düşünülmektedir. 
Tablo 9. E-Dönüşümün Hizmet Maliyetini Artırmasına Yönelik Yanıtlar

\begin{tabular}{|l|l|l|}
\hline Cevap & Gözlem Sayısı & Yüzde \\
\hline Kesinlikle Katılmıorum & 19 & 11,7 \\
\hline Katılmıyorum & 7 & 4,3 \\
\hline Fikrim Yok & 31 & 19,1 \\
\hline Katıliyorum & 34 & 21,0 \\
\hline Kesinlikle Kat1lyyorum & 71 & 43,8 \\
\hline
\end{tabular}

E-dönüşümün, muhasebe meslek mensuplarının hizmet maliyetini artırmasına yönelik yanıtları Tablo 9'da verilmiştir. Çalışmaya katılan katılımcıların sadece yüzde 16'sı hizmet maliyetlerine etkisi olmadığını beyan etmişlerdir. Tabloda verilen yanıtlardan e-dönüşümün muhasebe meslek mensuplarının hizmet maliyetlerinin artmasına neden olduğu, bu maliyetlerin mükelleflere yansıyacağı düşünülmektedir. E-dönüşümü daha cazip hale getirmek için, Maliye bakanlığı tarafindan, e-dönüşüme geçen mükelleflere teşvik ve muafiyetler getirmesinin önemli olduğu düşünülmektedir.

Tablo 10. E-dönüşüm Güvenli Bir Veri Saklama Olanağı Sunmasına Yönelik Yanitlar1

\begin{tabular}{|l|l|l|}
\hline Cevap & Gözlem Sayısı & Yüzde \\
\hline Kesinlikle Katılmıorum & 18 & 11,1 \\
\hline Katılmıyorum & 11 & 6,8 \\
\hline Fikrim Yok & 48 & 29,6 \\
\hline Katıliyorum & 41 & 25,3 \\
\hline Kesinlikle Katıliyorum & 44 & 27,2 \\
\hline
\end{tabular}

E-dönüşümün, güvenli bir veri saklama olanağı sunmasına yönelik muhasebe meslek mensuplarının yanıtları Tablo 10'da verilmiştir. Çalışmaya katılan katılımcıların yaklaşık yüzde 60’1 e-dönüşümün güvenli bir veri saklama hizmeti sunduğunu beyan etmişlerdir.

Tablo 11. E-Dönüşüm Paydaşlara Sunulan Bilginin Güvenliğini Artırmasına Yönelik Yanitlar1

\begin{tabular}{|l|l|l|}
\hline Cevap & Gözlem Sayıs1 & Yüzde \\
\hline Kesinlikle Katılmıorum & 20 & 12,3 \\
\hline Katılmıyorum & 9 & 5,6 \\
\hline Fikrim Yok & 46 & 28,4 \\
\hline Katıllyorum & 43 & 26,5 \\
\hline Kesinlikle Katıliyorum & 44 & 27,2 \\
\hline
\end{tabular}


E-dönüşümün, paydaşlara sunulan bilginin güvenliğini artırmasına yönelik muhasebe meslek mensuplarının yanıtları Tablo 11'de verilmiştir. Çalışmaya katılan katılımcıların yaklaşık yüzde 70’i, e-dönüşümün paydaşlara sunulan bilginin güvenliğini artırdığını beyan etmişlerdir. $\mathrm{Bu}$ beyanlar esas alındığında e-dönüşümün paydaşlara (Devlet, Yatırımcı, Ortaklar, Çalışanlar vb) güvenli bilginin sağlanmasında önemli bir rol oynadığı düşünülmektedir.

Tablo 12. E-Dönüşüm Bütün İnternet Browserlarında Kolaylıkla Kullanılabilmesine Yönelik Yanitları

\begin{tabular}{|l|l|l|}
\hline Cevap & Gözlem Sayısı & Yüzde \\
\hline Kesinlikle Katılmıorum & 38 & 23,5 \\
\hline Katılmıyorum & 22 & 13,6 \\
\hline Fikrim Yok & 58 & 35,8 \\
\hline Katıliyorum & 26 & 16,0 \\
\hline Kesinlikle Katıliyorum & 18 & 11,1 \\
\hline
\end{tabular}

E-dönüşümün, bütün internet browserlarında kolaylıkla kullanılabilmesine yönelik muhasebe meslek mensuplarının yanıtları Tablo 12'de verilmiştir. Çalışmaya katılan katılımcıların yaklaşık yüzde 65'i, e-dönüşümün bütün internet browserlarında kolaylıkla kullanılamadığını beyan etmişlerdir. Katılımcılara anketin son bölümünde açık uçlu sorular yöneltilmiştir. Açık uçlu sorulara verilen yanıtlardan yaşanan problemlerin bir kısmının internet browserlarından kaynaklandığı tespit edilmiştir. Maliye bakanlığı yetkililerinin en kısa sürede gerekli alt yapı çalışmalarını tamamlayarak bu sorunu gidermesinin önemli olduğu düşünülmektedir.

Tablo 13. E-Dönüşüm Mükelleflerime Ek Maliyet Getirmesine Yönelik Yanıtları

\begin{tabular}{|l|l|l|}
\hline Cevap & Gözlem Sayısı & Yüzde \\
\hline Kesinlikle Katılmiyorum & 15 & 9,3 \\
\hline Katılmıyorum & 8 & 4,9 \\
\hline Fikrim Yok & 20 & 12,3 \\
\hline Katıliyorum & 31 & 19,1 \\
\hline Kesinlikle Katıliyorum & 88 & 54,3 \\
\hline
\end{tabular}

E-dönüşümün, mükelleflere ek maliyet getirmesine yönelik muhasebe meslek mensuplarının yanıtları Tablo 13'de verilmiştir. Çalışmaya katılan katılımcıların yüzde 73,4'ü gibi büyük oranda, e-dönüşümün bütün mükelleflere ek maliyet getirdiğini beyan etmişlerdir. Katılımcılara anketin son bölümünde açık uçlu sorular yöneltilmiştir. Açık uçlu sorulara 
verilen yanttlardan, e-dönüşümden kaynaklı ek maliyeti, mükelleflerin, muhasebe meslek mensubuna ödemekten kaçındığı tespit edilmiştir. TÜRMOB'un Maliye Bakanlığı ile görüşerek en kısa sürede, Serbest Muhasebecilik, Serbest Muhasebeci Mali Müşavirlik ve Yeminli Mali Müşavirlik Asgari Ücret Tarifesi'ni güncellemesinin, bu sorunun giderilmesine önemli bir katkı sunacağı düşünülmektedir.

Tablo 14. ” E-Dönüşüm İçin Etkin Biriyim” Sorusuna Yönelik Yanttlar

\begin{tabular}{|l|l|l|}
\hline Cevap & Gözlem Sayıs1 & Yüzde \\
\hline Kesinlikle Katılmıyorum & 11 & 6,8 \\
\hline Katılmıyorum & 14 & 8,6 \\
\hline Fikrim Yok & 36 & 22,2 \\
\hline Kat1lyyorum & 41 & 25,3 \\
\hline Kesinlikle Kat1liyorum & 60 & 37,0 \\
\hline
\end{tabular}

"E-dönüşüm için etkin biriyim” sorusuna yönelik muhasebe meslek mensuplarının yanıtları Tablo 14'de verilmiştir. Çalışmaya katılan katılımcıların yüzde 62,3'ü e-dönüşümde yetkin olduklarını beyan etmişlerdir.

\section{SONUÇ VE ÖNERILLER}

Ticari ve mali işleyişin önemli aktörlerinden biri hiç kuşkusuz Maliye Bakanlığıdır. Maliye Bakanlığı bilgi teknolojilerindeki bu değişime yönelik olarak, vergi gelirlerini artırmak, vergi toplama maliyetini düşürmek, kayıt dış1lı̆ın önüne geçilmesi, şeffaf ve daha kontrollü bir ortam oluşturulması, işlemlerin daha hızlı ve ulaşlabilir hale getirilmesi ve ayrıca vergi denetimlerinin etkinliğini artırmak amacı ile e-dönüşümü başlatmıştır.

Maliye Bakanlı̆̆ tarafından e-dönüşüme yönelik belirlenen hedeflere, maliye bakanlığının yayınlamış olduğu raporları esas alındığında, ulaşıldığı görülmektedir.

$\mathrm{Bu}$ araştırmanın temel amacı, muhasebe meslek mensuplarının Maliye Bakanlığının edönüşümü sürecine ilişkin, bakış açıları, yaşadıkları sorunlar, çözüm önerileri, iş yüklerine etkisi ve hizmet maliyetlerine etkisini tespit etmek amacı ile yapılmıştır.

Araştırma kapsamında muhasebe meslek mensuplarının e-dönüşüme ilişkin olarak;

E-dönüşümün, mükelleflere ek maliyet getirmiş olmasına karşın, mükelleflerin, e-dönüşümden kaynaklı ek maliyeti, muhasebe meslek mensubuna ödemekten kaçındığı tespit edilmiştir. TÜRMOB ve Maliye Bakanlığı gerekli çalışmaları yaparak e-dönüşüme bağlı olarak hizmet maliyeti artan muhasebe meslek mensuplarının asgari ücret tarifelerinde güncelleme yapılması gerektiği düşünülmektedir. 
$>\quad$ E-dönüşümde muhasebe meslek mensupları, internet browserlarından kaynaklı sorunlar yaşadıkları tespit edilmiştir. Maliye Bakanlığı yetkililerinin en kısa sürede gerekli alt yapı çalışmalarını tamamlayarak bu sorunu gidermesinin önemli olduğu düşünülmektedir.

$>\quad$ Muhasebe paket programları sunan şirketlerin e-dönüşüm için yeterli teknik alt yapıyı muhasebe meslek mensuplarına sundukları tespit edilmiştir.

> Muhasebe meslek mensuplarının yüzde 83,3'nün e-dönüşüm sürecinde, en az bir kez hata yaptıkları tespit edilmiştir. Muhasebe meslek mensuplarının eğitim yetersizlikleri, sistemsel hatalar ve kullandıkları programdan kaynaklı sorunlar bu yüksek oranda hata yapılmasının nedeni olabileceği düşünülmektedir.

Çalışmamızda, meslek mensuplarının yüzde 82,1'inin lisans mezunu olduğu buna karşın yüksek lisans dercesine sahip olan muhasebe meslek mensubu sadece yüzde 17,9 olduğu tespit edilmiştir. Meslek mensuplarının güncel gelişmeleri takip edebilmeleri için ve ayrıca teoriyi uygulamaya dönüşümünün hızlandırılması amacıyla lisansüstü eğitime teşvik edilmesi gerektiği düşünülmektedir.

\section{KAYNAKLAR}

Alptürk, Ercan, (2008), 'Elektronik Denetim Rehberi', Gelirler Kontrolörleri Derneği, İstanbul.

Amıdu, Mohammed,- John Effah, JosuaAbor, (2011), “E-Accounting Practices Among Small and Medium Enterprises in Ghana”, Journal of Managment Policyand Practice,12(4), pp. 146-155.

Çetin, Hüseyin - Tevfik Eren,(2015), "Muhasebe Meslek Mensupları Tarafından Bürolarda Kullanılan Muhasebe Paket Programı Seçimi: Konya İline Yönelik Bir Araştırma”, Atatürk Üniversitesi İktisadi ve İdari Bilimler Dergisi, 29(1), ss. 83-100.

Çınar, Orhan - Selami Güney, (2012), "Muhasebe Meslek Mensuplarının E-Sorular Hakkındaki Görüşleri: Erzurum Örneği”, Ekev Akademi Dergisi, 16(50), ss. 259-272.

Doğan, Uğur, (2012), '100 Soruda e-Defter', Vergi Sorunları Dergisi, 280, ss. 5-73

European Commission, (2010), Reaping the Benefits of Electronic Invoicing for Europe, Brussels, https://www.europeanpaymentscouncil.eu/news-insights/insight/reapingbenefits-electronic-invoicing-europe, (16.03.2017).

Gökçen, Gürbüz - Mustafa Özdemir, (2016), “Türkiye'de Muhasebe Uygulamalarından EDefter ve E-Fatura Uygulaması", Marmara Üniversitesi Öneri Dergisi, 12(46), ss. 137154.

Güney, Aysel, (2014), “Role Of Technology in Accounting and e-accounting”, Socialand Behavioral Science, 152, pp. 852-855. 
Güney, Selami - Hüseyin Özyiğit, (2015), "Muhasebedeki Verilerin Yönetimde Kullanılması ve Elektronik Muhasebe Verilerinin Yönetim Kararlarına Etkisi”, Elektronik Sosyal Bilimler Dergisi,14(53), ss. 279-297.

Hacırüstemoğlu, Rüstem, (2008), "Bilgi Çağında Muhasebe Eğitimi”, Muhasebe Bilim Dünyası Dergisi, 10(4), ss. 1-6.

Hatunoğlu, Zeynep - İsmail Bakan, (2010), "Muhasebe Bürolarında Bilgisayar ve İnternet Kullanımının Faydaları ile İş Yeri Özellikleri Arasındaki İlişki: Bir Alan Araştırması”, Mustafa Kemal Üniversitesi Sosyal Bilimler Enstitüsü Dergisi, 7(13), ss. 88-129.

Lian, Jiunn-Woei, (2015), “Critical Factors for Cloud Based e-Invoice Service Adoptaion in Taiwan: An EmpiricalStudy”, International Journal of Information Management, 35, pp. 98-109.

Marınag1, Catherine C. Trivellas- Panagiotis Reklitis, C.Skourlas, (2015), “Adoption and Use of E-Invoicing in Greece”, International Conference on Integrated Information, 1644, pp. 279-286.

Nakip, Mahir, (2006), Pazarlama Araştırmaları, Ankara: Seçkin Yayıncılık

Spoz, Anna,(2014), “A Look at e-invoices From Enterprises and Goverment’s Perspective”, Research Papers of Wroclaw University of Economics, 365, pp. 254-264.

Tektüfekçi, Fatma, (2013), 'Bilişim Teknolojilerindeki Gelişmelerin Muhasebe Uygulamalarına Etkisi: E-Muhasebe', Sosyal ve Beşeri Bilimler Dergisi, 5(2), ss. 89102.

Tektüfekçi, Fatma, (2016), 'E-Dönüşüm Sürecinde Elektronik Muhasebe Uygulamaları', Kitapana Yayınları, İzmir.

www.edefter.gov.tr (06.03.2017)

www.efatura.gov.tr (06.03.2017) 